\title{
Trendsetter Muballigh di Medsos: Analisis Framing Instagram Felix Siauw dan Hanan Attaki
}

\author{
Nor Latifah ${ }^{\mathrm{a}, 1, *}$, Romario $^{\mathrm{b}, 2}$ \\ ${ }^{a}$ Uviversitas Islam Negeri (UIN) Sunan Kalijaga, Yogyakarta 55122, Indonesia \\ ${ }^{b}$ Uviversitas Islam Negeri (UIN) Sunan Kalijaga, Yogyakarta 55122, Indonesia \\ ${ }^{1}$ latifahnorlatifah76@gmail.com *; ${ }^{2}$ roma02711@gmail.com
}

ARTICLE INFO

Article history:

Received : 2019-01-31

Revised : 2019-04-09

Accepted : 2019-05-23

Keywords:

Trendsetter

Ustadz Hitz

Instagram

Kata Kunci:

Trendsetter

Ustadz Hitz

Instagram

\section{ABSTRACT}

The increasing use of Instagram is dominated by users around the age of 15-30 years. The majority who followed in Instagram were famous public figures such as celebrities, political figures and religious leaders. With this Instagram, da'i or preachers can convey their messages easily and free through photos and captions or short videos. This study is important to see how Instagram as a new media is able to become a trendsetter for wellknown Ustadz like Felix Siauw and Hanan Attaki. This study uses a qualitative research method using the framing model as proposed by Robert N. Entman by observing how a discourse or communication is displayed in the public space. The finding confirmed that the framing model of Felix Siauw and Hanan Attaki has similarities in preaching Islam through Instagram social media using short posts or short videos and interesting captions. However, both of them have different tendencies, in which Felix Siauw is more dominant in discussing social and political issues while Hanan Attaki is more dominant in discussing good advice or about love between men and women.

\section{ABSTRAK}

Penggunaan Instagram semakin meningkat yang didominasi pengguna sekitar umur 15-30 tahun. Mayoritas yang diikuti masyarakat dalam instagram adalah public figure yang terkenal seperti seleberitis, tokoh politik dan tokoh agama. Dengan instagram ini pula para da'i atau pendakwah bisa menyampaikan pesannya dengan mudah dan gratis melalui foto serta caption maupun video singkat. Kajian ini penting untuk melihat bagaimana Instagram sebagai media baru mampu menjadi trendsetter dakwah bagi Ustad Hitz seperti Felix Siauw dan Hanan Attaki. Penelitian ini menggunakan metode penelitian kualitatif dengan menggunakan framing modeldikembangkan oleh Robert $N$. Entman dengan mengamati bagaimana sebuah wacana atau komunikasi ditampilkan diruang publik. Hasil dari penelitian ini menunjukan framing model Felix Siauw dan Hanan Attaki memiliki kesamaan dalam berdakwah melalui sosial media instagram dengan menggunakan postingan atau video pendek dan caption yang menarik. Namun keduanya memiliki kecendrungan yang berbeda dimana Felix Siauw lebih dominan membahas permasalah sosial dan politik sedangkan Hanan Attaki yang lebih dominan membahas tentang nesehat kebaikan atau tentang cinta antara laki-laki dan perempuan.

Copyright $\odot 2019$ IAIN Palangka Raya. All rights reserved.

\section{Pendahuluan}

Sosial media telah menjadi ruang publik Islam dimana terjadi peningkatan pendakwah Islam populer di Indonesia. Hal tersebut menunjukan bahwa media baru telah memperluas ruang publik Islam sebagai identitas, tempat ide, dan wacana. Sosial media menjadi tempat bagi siapapun dan dimanapun untuk bisa mengakses fatwa yang 
disampaikan pendakwah.(20) Narasi yang bersifat sederhana lebih bisa ditangakap oleh pengguna sosial media apalagi jika narasi tersebut terkait dengan isu agama dan nasionalisme maka memiliki aktivisme yang lebih besar. Hal tersebut akhirnya membuat pergeseran otoritas atas nama agama yang biasanya dipegang oleh ulama arus utama kini beralih ke ulama baru yang aktif menggunakan sosial media sebagai tempat dakwah. Sehingga terjadi kontestasi di antara ulama arus utama dan ulama baru di sosial media.(10)

Pada masa sosial media ini yang memanfaatkan berbagai macam postingan yang berkenaan dengan foto, video, kata-kata motivasi pada akhirnya memunculkan Ustadz Hits. Ustadz Hits berbeda dengan ustadzustadz seleb sebelumnya yang menjadi primadona dimasa televisi mereka pada umumnya terkenal berkat sosial media. Misalnya seperti Muzammil Hasballah yang terkenal berkat unggahan video ketika dia menjadi imam sholat di ITB, Felix Siauw yang terkenal dengan cetusan tagarnya \#UdahPutusinAja, serta beberapa ustadz seperti Hanan Attaki, Khalid Basalamah, dan Syafiq Reza Basalamah.(7)

Penggunaan sosial media lebih khusus di Instagram juga semakin meningkat yang didominasi pengguna sekitar umur 15-30 tahun. Pada Juni 2018 penguna aktif bulanan instagram mencapai 1 miliar.(16) Mayoritas yang diikuti masyarakat dalam instagram adalah public figure yang terkenal seperti seleberitis, tokoh politik, dan tokoh agama. Dengan instagram para dai atau pendakwah bisa menyampaikan pesanya dengan mudah dan gratis melalui foto serta caption maupun video singkat.

Sosial media khususnya Instagram telah menjadi tempat mediasi bagi berbagai hal yang berkaitan dengan keagamaan. Studi mengenai Instagram dan hubungan dengan perilaku keagamaan mejadi hal yang baru dalam perkembangan sosial media dan baru ditulis oleh sejumlah orang, Nisa dalam penelitiannya menunjukan bahwa Instagram mampu menarik perhatian perempuan Muslim Indonesia dengan membangun image bagaimana menjadi perempuan muslimah yang tepat dalam melakukan perjalanan hijrah.(17) Tujuan dari akitivitas tersebut adalah meningkatkan dan menekankan tentang kehidupan Islam yang ideal dan mencapai kebahagiaan tertinggi. Melalui postingan di Instagram, para aktivis tersebut mendorong untuk menggunakan jilbab syar'i dan membatasi interaksi bebas antara pria dan wanita. Para aktivis menggunakan dakwah Instagram untuk memperkuat resolusi pemuda yang berpikiran sama yang ingin mengalami hijrah dengan mengadopsi apa yang mereka yakini sebagai pemahaman Islam yang lebih baik.(17)

Begitu juga dengan yang mengkaji tentang akun Instagram biro jodoh. Taaruf Nikah yang telah sukses menjodohkan Muslim Indonesia. Hal tersebut dilakukan dengan cara melakukan pembayaran Rp. 100.000. selain itu juga akun tersebut sering memposting foto dan video yang mengenai seorang Muslim menghindari pacaran, dan segera menikah karena Allah. Hal tersebutlah yang seringkali menarik pemuda muslim Indonesia yakni dengan adanya komodifikasi agama, khusunya berkenaan dengan saleh tidaknya seseorang.(18)

Topik mengenai Instagram juga pernah dibahas khususnya mengenai kontestasi pemaknaan Hijab dengan mengkaji komunitas Hijabber Community dan Niqab Squad yang telah menjadi sebuah simbol Islam di ruang publik dan dipahami sebagai bentuk Islam $k a f f a h$. Dengan didukungnya media Instagram kedua komunitas tersebut aktif mempromosikan melalui dakwah kreatif. Hijabber Community yang mempersentasikan simbol muslimah yang stylist, gaul, trendy dan fashionable dilain sisi Niqab Squad mempersentasikan simbol muslimah bercadar yang serba hitam yang memegang teguh ajaran Islam dengan ketat. Terlepas dari kontradiksi yang dipresentasikan, kedua komunitas tersebut mengakomodasi teknologi informasi dan modernitas untuk mengasosiasi antara ortodoksi dan tantangan modernitas. Hijabber Community yang bertujuan untuk menghilangkan stigma negatif perempuan berhijab yang terdemestifikasi dan tertindas, sedangkan Niqab Squad yang memiliki tujuan menghilangkan stigma negatif perempuan muslim bercadar yang seringkali dianggap ekstremisme dan fundamentalisme Islam.(13)

Studi-studi sebelumnya cenderung mengkaji fenomena akun-akun yang berkaitan 
dengan kesalehan seperti menjadi perempuan yang sholeh, taafur, dan pemaknaan hijab. Artikel ini menampilkan hal yang berbeda dengan memfokuskan postingan dari Ustdaz Hitz yang populer di Instgram yakni Felix Siauw dan Hanan Attaki. Untuk penelitian mengenai Felix Siauw sebenarnya telah dilakukan dengan hasil penelitiannya menyatakan bahwa model dakwah Felix Siauw yakni persimpangan antara kegiatan online dan acara offline dalam dakwah Islam kontemporer; berbagai bentuk ekspresi lisan, teks dan visual dakwah offline; dan politik dan puitis dakwah. Selain itu dikatakan juga bahwa Felix memiliki afiliasi dengan HTI, dalam penelitian terakhir dikatakan bahwa Felix mengikuti pengikut di Instagram sebanyak satu juta. Pada tahun 2019 pengikut Instagram Felix Siauw mengalami peningkatan sebanyak 3,5 Juta.(20) Artikel ini hanya fokus terhadap Instagram Felix Siauw untuk melihat narasi yang dikembangkannya khusunya setelah terjadi pembubaran HTI pada tahun 2017. Begitupun juga dengan Hanan Attaki yang berfokus kepada kegiatan dakwah yang dilakukan Ustadz Hits seperti Hanan Attaki dan Evie Effendi, dan melihat fenomena gerakan pemuda hijrah dimana gaya dakwah mereka memiliki pola berbeda dengan ulama sebelumnya, dimana mereka menggunakan gaya yang sesuai dengan anak muda dan juga pakaian yang serba gaul.(8) Penelitian sebelumnya mengenai Felix Siauw telah mengkaji mengenai gaya berdakwah dan pesan Felix Siauw di facebook (6) sedangkan penelitian mengenai Hanan Attaki telah mengkaji mengenai gaya berdakwah dan pesan Hanan Attaki di Youtube.(1) Tulisan ini menampilkan hal yang berbeda dengan memfokuskan postingan Felix Siauw dan Hanan Attaki di instagram yang telah menjadi trendsetter dakwah yang pada kajian sebelumnya hanya memfokuskan kepada gaya berdakwah.

Felix Siauw dan Hanan Attaki dipilih sebagai fokus kajian kerena mereka merupakan Ustadz Hitz yang muda dan memiliki pengikut yang banyak. Dakwah mereka yang kreatif dan lebih banyak menarik perhatian anak muda. Instagram telah menjadi soft or light dakwah. Dimana dalam hal ini dakwah bukan hanya mengenal bahasa verbal namun juga bahasa visual yang memuat konten positif dan ujaran yang mengandung motivasi dalam postingan. Tulisan ini mengekplorasi otoritas Ustadz Hitz melalui postingan Instagram. Eksplorasi penulis fokus pada sejumlah postingan baik foto ataupun video yang di unggah di Instagram. Studi ini ingin melihat tresndsetter dakwah yang dilakukan Felix Siauw dan Hanan Attaki. Tulisan ini setidaknya mendiskusikan tiga pertanyaan. Pertama, Bagaimana trendsetter mubaligh di Instagram?, Kedua, seperti apa trendsetter Felix Siauw dan Hanan Attaki? Ketiga, bagaimana Felix Siauw dan Hanan Attaki menarik perhatian anak muda melalui postingannya?

Untuk menjawab pertanyaan tersebut. Pertama, tulisan ini akan membahas mengenai Trendsetter dan bagaimana trendsetter mubaligh di Instagram, kedua, seperti apa propogansi Islam melalui trendsetter di instagram dan apa tantangan dan peluang propogasi dalam Islam di Instagram. Pada bagian ketiga, penulis menyajikan metodologi dan analisis penelitian terkait postingan foto dan video Felix Siauw dan Hanan Attaki di Instagram sebagai ruang otoritas keagamaan. Terakhir tulisan ini ditutup dengan kesimpulan.

\section{Tinjauan Pustaka}

\section{a. Pengertian Trendsetter}

Secara leksikal, trendsetter yang artinya "One that sets a trend"(22) Apabila dihubungkan terhadap dunia IKOM, trendsetter akan muncul terhadap kehidupan makhluk sosial mengcover kata pendek menggulung rute. Semasa itu pulpen sulit didapatkan. Tatkala pena didapatkan, trend pun berpindah alih kertas ditulis untuk kata pendek via burung merpati. Alat tulis pun hadir, kemudian IT mulai bermunculan, contohnya internet dan lain-lain. Akan tetapi, beraneka macam media tidak seluruhnya bisa memposisikan antara yang satu dengan yang lain. Seperti kertas tidak bisa memerankan surat kabar, begitu pula surat kabar tidak bisa dialihkan dengan IT. Karena masing-masing mempunyai kualitas tersendiri.

Berangkat dari masa cyberspace, apapun form wahana wacana yang sering dijumpai: secara langsung, telepon, fax, surat, surat kabar, majalah, radio, dan televisi. Pada era sekarang film sudah mengalihkan ke teleseminar (telekonferensi). Jadi, teleseminar 
itu biasanya orang menyebut dengan teleconference. Definisi dari teleconference yaitu komunikasi sebagian orang secara konvensional terhadap rute ataupun ruang lingkup bahkan dikaitkan melalui suatu sistem telekomunikasi. Sistem telekomunikasi yang bisa dijadikan sebagai penyokong telekonferensi adalah memfasilitasi antara yang satu ataupun yang lain seperti record, gambar, atau sebuah fasilitas data satu ataupun yang lain misalnya komputer, telegraf, teletif, radio, dan tv. Adapun contoh yang lain seperti telepon internet, fax internet, e-mail berupa surat ataupun majalah, dan muculnya berupa sosial jaringan dalam digital instrument sebagai trendsetter pada masa ini.(15) Adanya jaringan komputer yang disebut internet. Internet telah diterima oleh kehidupan masyarakat. Adapun kita telah berjumpa dengan semua bentuk pola wacana yang diketahui berkonvergensi menyebar di setiap sudut, biasanya bisa dikatakan sebagai multimedia.

Berangkat dari sebuah definisi "media digital baru", definisi tersebut dikembangkan oleh Ito dan kawan-kawan(12) media itu merupakan perihal aset dari kemajuan IT mulai terbagi menjadi sebuah set media yang tidak bermanfaat apabila bertumpuk dengan sendirinya. Misalnya media digital baru yang sering dikenal dengan sebutan "MDB" yaitu: game concoles (GC), telepon genggam, personal digital assistants, komputer, dan seluruhnya yang bisa terkoneksi. Bahkan teknologi membuat semua makhluk sosial yang dulu terbatas sekarang sudah memenuhi apa yang diperlukan oleh manusia. Perkembangan IT di era digital menentukan ke arah efek baik maupun tidak baik. Efek yang terlihat akan secara jelas mulai dari perkembangan atau kemenangan dari sebuah teknologi dan informasi (IT).

\section{b. Trandsetter Mubaligh di Instagram}

Instagram merupakan bagian dari elemen-elemen wadah online di era digital yang mengharuskan user bisa berkontribusi untuk menemukan globe bagi user. Wadah sosmed semakin bertambah pesat untuk keperluan pokok atau fundamental bagi masyarakat di era modern. Tidak pilih kasih muda atau tua, mulai dari bocah, anak-anak "ingusan" bahkan dewasa terlarut dalam kenangan memori di sosial media. Misalnya instagram, youtube, facebook, bahkan sampai media sosial lainnya menjadi sebuah trendsetter komunikasi digital secara mendunia seakan menjadi rumah kedua wadah persinggahan sebagai keluh dan kesah. Berikut adalah contoh berbagai channel jaringan komunikasi sosial yang menjadi trendsetter pada sekarang ini:

\begin{tabular}{ll}
\hline Type & Examples \\
\hline Social networking sites & Facebook, Google+, LiveMocha \\
Collaborative media & Wikis \\
Blogs and Microblogs & Blogger, Twitter \\
Content communities & Youtube, Picasa \\
Virtual game worlds & Warcraft \\
Virtual social worlds & Second life
\end{tabular}

Gambar 1. Trendsetter Jaringan Komunikasi Sosial(2)

Pada relasi eksistensi dan kapasitas sains, terutama IT terhadap Islam sebagai sistem nilai, perkawinan antara teknologi penyebaran secara aktual serta benda yang canggih, seperti laptop yang muncul di era sekarang, merupakan sebagai masa berita bukan termasuk negeri tanah air yang ikut memerankan didalamnya. Adapun menurut Cherry bahwa kemajuan TI dan isu berita secara kilat bisa dikatakan sebagai explosion, adalah Pertama, sebagai TI yang terpendam secara kuadrat geometrik. Kedua, kesempurnaan TI secara eksklusif seperti software ataupun hardware.

Imbas dari kemajuan teknologi IT menyebabkan masyarakat Indonesia mengalami kesulitan untuk mengendalikan berkembangnya arus informasi yang besar dan pesat. Maka untuk mengatasi hal tersebut perlu adanya langkah-langkah dalam pengendalian informasi yang tepat dalam upaya melindungi informasi yang kurang baik. Menurut Bakti efek dari berkembang pesatnya sains dan IT, khususnya dalam komunikasi, Menyebabkan "globalisasi". Hal tersebut dapat dilihat dari mengglobalnya istilah $5 \mathrm{~F}$ (Fun, fashion, Food, Facility, dan Fantacy). Pertama, Fun dikemas dalam bentuk hiburan baik yang berbentuk VCD, $\mathrm{CD}$, film, baik dalam bentuk televisi yang ditonton sehari-hari maupun biokop. Begitu juga dengan lagu-lagu yang berasal dari negara lain seperti Mariah Carey dan Celine Dion bisa kita jumpai di mall, rumah-rumah, ataupun di bus-bus. Kedua, Fahion (mode) yakni segalah mode pakaian yang sedang mendunia yang bisa kita jumpai ketika berada 
dipelosok kecil sekalipun. Mode pakaian seperti "you can see" maupun "Belly Botto" dapat kita jumpai di sentral pertokoan ataupun mall. Ketiga, Food selera makanan seperti Pizza Hut, KFC, McDonald bisa dikonsumsi oleh masyarakat yang menginginkannya. Keempat, Facility seperti mobil yang mereknya mendunia dapat kita jumpai diberbagai jalan raya misalnya Mercedez benz atau BMW. Dan yang terakhir Fantacy ditandai dengan persebaran obat-obatan yang merangsang rasa fantasi yang biasanya dijajarkan oleh bar-bar dan dikonsumsi oleh anak-anak belasan tahun. Meskipun begitu tak seluruh dunia menjadikan hal tersebut sebagai style hidup, namun demikianlah keadaan masyarakat dunia pada era globalisasi.

\section{c. Propagasi Islam Melalui Trendsetter di Instagram}

Secara spesifik propagasi bisa diartikan sebagai penyebaran atau penyiaran. Propagasi bisa di artikan dengan kata dakwah, dakwah berarti hal yang dilakukan untuk mengajak manusia mengikuti petunjuk yang telah diberikan Allah dan Rasul-Nya.(11) Namun para pakar memaparkan definisi dakwah adalah menampilkan aktifitas yang bertujuan untuk perubahan positif dalam diri manusia.(2) Seiring dengan berkembangnya zaman dakwah pun ikut mengalami perkembangan. Hal tersebut dapat dilihat dari metode dakwah dan media yang dipakai untuk menyebarkan dakwah. Kemunculan dari sosial media seperti twitter, line, path, facebook, maupun instagram dimanfaatkan sedemikian rupa sebagai mediasi menyampaikan dakwah. Media sosial memiliki kemampuan yang lebih dari pada SMS ataupun telepon yang hanya terhubung denga orang tertentu saja, sedangkan media sosial memiliki jangkauan yang lebih luas dan menjadi tempat mediasi yang efektif untuk menyebarkan dakwah. Maka dengan berkembang pesatnya teknologi metode berdakwahpun juga harus dipertimbangkan untuk bisa menyesuaikan dengan perkembangan zaman agar dakwah menjadi suatu hal yang selalu dapat diterima dan tidak usang dimakan zaman. Meskipun disisi lain perkembangan atas teknologi dan informasi tak semuanya menuai positif. Teknologi informasi layaknya pisau bermata dua yaitu mempermudah atau memperingan pekerjaan kita namun disisi lain juga mampun memudahkan kita untuk membuat citra buruk terhadap orang lain. Hal ini karena memang segala kemajuan teknologi informasi tergantung kepada siapa yang menggunakannya bila ditangan orang baik maka akan menghasilkan manfaat, sebaliknya juga bila teknologi informasi berada ditangan yang kurang tepat maka buruklah juga hasilnya. Sebagai pengguna sosial media amatlah penting untuk memanfaatkan atau mengarahkan apa yang digunakan dalam kemajuan teknologi. Salah satu sosial media yang dimanfaatkan untuk menyebarkan dakwah adalah Instagram.

Instagram sebagai salah satu platform yang tersedia disosial media atau disebut juga sebagai new media communication. Persebaran informasi yang diunggah oleh pengguna Instagram bisa menjadi bahan infrormasi bagi pengguna Instagram lainnya melalui konsep penerimaan, pertukaran, ataupun penyebaran informasi yang mana semua hal tersebut menjadi perwujudan atas cyber society.

Layaknya sosial media lainnya pengoperasian Instagram mengenai informasi berjalan cepat dan efektif. Hanya saja yang membedakannya adalah dimana sosial media Instagram lebih konsen kepada foto ataupun video pendek yang berdurasi 1 menit. Istagram memiliki sistem pertemanan dengan istilah following dan follower. yang mana artinya following adalah aku yang kita ikuti, sedangkan follower adalah pengguna lain yang mengikuti kita. Interaksi pengguna Instagram dapat dilihat melalui respon like (suka) maupun dengan memberikan komentar.

Tampilan yang dimiliki Instagram terlihat lebih sederhana dan bisa dipahami dengan mudah sehingga memudahkan pengguna dari berbagai kalangan untuk menelusuri tiap fiturnya. Hal ini merupakan salah satu daya tarik Instagram. Bambang menyatakan bahwa Instagram mempunyai lima menu utama pada yakni : Home page, Populae, Take Photo, New Feeds dan Profile.(3)

Saat ini, fitur-fitur Instagram selalu bertambah di setiap pembaharuannya, saat ini Instagram mempunyai fitur Instagram story, yang mana pengguna bisa mengupdate foto, video bahkan link (situs) yang akan hilang 
atau dapat di lihat oleh pengguna lain dalam kurun waktu 24 jam. Fitur ini terdapat pada bagian atas Instagram, yang mana pengguna Instagram dapat saling berbagi, menerima serta menyebarkan informasi dalam bentuk story tersebut.

Alasan lain kenapa Instagram disukai para warga net adalah tawaran media sosial yang lebih menonjolkan pada foto dan video pendek untuk bisa berinteraksi diantara pengguna Instagram selain itu ditambah juga dengan filter yang bergaya retro.(3)

Sama halnya juga dengan sosial media lainnya Instagram memiliki sifat real time. Dimana setiap detik kapanpun dan dimanapun berbagai macam foto dan video yang jumlahnya ribuan bahkan sampai jutaan dan Instagram Story telah menyebar sedemikian rupa. Selain itu juga Instagram memiliki kemampuan untuk bisa menyebarkan gagasan dan ide sebagai tempat aktualisasi diri. Untuk lebih spesifiknya kekuatan yang dimiliki Instagram adalah sebagai berikut: Pertama, Take photo dan video merupakan fitur untuk bisa memposting segala foto dan video yang terdapat dalam galeri foto smarthphone. Kedua, Comment adalah sebuah komentar yang diberikan atas apa yang diposting oleh pengguna lainnya. Ketiga, Caption merupakan penjelasan mengenai foto atau video yang pengguna unggah, biasanya caption ini memberikan keterangan informasi yang detail mengenai informasi yang di bagikan oleh pengguna. Keempat, Hastag merupakan sebuah simbol (tag) berupa suatu kata yang diberi awalannya dengan simbol pagar (\#) untuk mengelompokkan foto disuatu label tertentu, sehingga informasi berupa foto atau video yang dibutuhkan lebih mudah dicari dan ditemukan oleh pengguna lain. Kelima, Mention adalah fitur yang digunakan untuk bisa menyapa pengguna lainnya. Keenam, Tag adalah fitur yang digunakan untuk menandai teman atas postingan foto dan video yang diunggah.

\section{d. Tantangan dan Peluang Propagasi Islam di Instagram}

Pertama kali benda media baru digital yang hadir di dunia yaitu yang terutama komputer dan telepon genggam yang terhubung dengan "Net" sebagai bagian dari produk perkembangan IT wacana yang terbaru bisa menjadi sarana penyampaian secara islami, serta sampai tua mereka mengganggap bahwa media penyiaran agama Islam. Adapun manfaat dari sosial media adalah media penyiaran islami menurut dari sebagian golongan masyarakat, baik dari segi orang tua, remaja, sampai anak-anak. Mereka menganggap bahwa media penyiaran agama Islam itu penting bagi mereka. Bahkan negara-negara Muslim harus totalitas membentangkan dan membuka asal muasal traditional komunikasi, misalnya jurnal ilmiah atau karya ilmiah yang bernunasa Islami ataupun pembentukan jejaring informasi yang relatif rendah dan mempertimbangkan secara khusus untuk memadukan dan mengemukakan ide antara para ilmuan bahkan intelektual Muslim.(2)

Tantangan yang dihadapi di Instagram, bisakah kita terima? Misalkan diibaratkan dalam segala sesuatu yang mempunyai keuntungan dan kekurangan, peradaban IT di era modern ini jelas akan mengantarkan ke efek positif dan negatif. Eksistensi publikasi informasi adalah alat efesien dalam penyebaran isu. Mubaligh atau dai (Guru) wajib belajar untuk mengikuti kemajuan IT maka siaran Islami bisa terarah secara efisien dan bisa termuat secara berita update dalam era digital hingga bisa mengerti dengan pertumbuhan selama ini bahkan bisa memanfaatkan secara pengkajian dengan muridnya. Ketidak mampuan dan ketidak tahuan dalam memanfaatkan media digital dalam sosial akan menciptakan penyampaian dakwah yang bernuansa Islam akan terus berjalan secara ortodoks dan ada batasan dari penelaahan itu sendiri.(2)

Adapun efek yang dipaparkan oleh Bakti tersebut yaitu dengan diberi julukan " $5 \mathrm{~F}$ " merupakan sebuah provokasi individu terhadap tindakan ataupun yang menerima. Menurunnya modal SDM ataupun nilai negeri orang Islam menginfor teknologi berita dari orang asing. Penjelasan beraneka macam mulai dari masalah seksualitas, perang, bahkan criminal yang memunculkan dampak berlawanan secara kontradiktif yang bertujuan untuk wacana atau berita tersebut. Kemajuan IT serba canggih dan spektakuler mengakibatkan orang-orang melupakan dirinya. Misalnya masyarakat bersifat individualistis, konsumeristik ataupun 
eksploitatif dari segi individu, masyarakat, dan sekitarnya. Adapun Tuhan pun begitu juga. Agama Islam merupakan sebuah tatanan yang ada relasinya berbentuk secara intikad yang memanipulasi bahkan memprediksi sedemikian sempurnanya yang berlandaskan sebagai rahmat bagi semesta dan mengajak atau menganjurkan hal-hal yang baik dan mencegah hal-hal yang buruk bagi masyarakat. Situasi tersebut merupakan sebagai provokasi untuk orang-orang yang beragama Islam di masa mendatang untuk menelusuri semua norma-norma yang berintikad nuansa islami.(2)

Peluang yang harus digunakan pada aspek didalam dunia Instagram yaitu pada aspek positif IT memiliki muslihat yang wajib kita ketahui dan pahami. IT yang lahir di Barat cenderung mengarah ke eskalasi unsur secara desktruktif ataupun penanganan secara khusus yang dipergunakan oleh klien asing. Adapun argumentasi yang paling berperan kenapa dunia orang Islam wajib memajukan potensi diri sendiri dalam sebuah IT ataupun bisa disebut dengan "Micro-Digital". Di negara industri bukan sekedar melindungi otoritas politik dan ekonomi, namun mereka juga akan menggerogoti bahkan menjatuhkan dunia.

Dengan via Instagram, setiap orang bisa menelusuri relasi personal ataupun terikat aktif dalam hal pembelajaran Islam dan bisa menciptakan community antar para profesional untuk berbagi informasi dan keahlian. Selain itu, komunikasi itu menumbuhkan dan menciptakan kekuatan motivasi. Apabila komunikasi sesuai dengan keinginan, inspirasi, value, definisi serta progres si penerima, sehingga mereka bisa mempengaruhi dan membentuk ciri-ciri wacananya.(2) Instagram juga memudahkan akses kepada siapa saja bahkan mempunyai dampak positif dalam penyiaran yang lebih leluasa terhadap lingkungan anak remaja. Para pendakwah bisa memanfaatkan sosial media Instagram untuk menyampaikan syiar yang bernuansa Islami, misal apa yang dilakukan oleh seorang mubaligh Felix Siaw dan Hanan Attaki.

Peluang propogasi Islam di media Instagram memiliki banyak manfaat dan keuntungan antara lain, Pertama, mampu mendobrak batasan celah-celah ataupun waktu pada sekilas mata dengan besar secara absolut. Kedua, user jasa net setiap tahunnya semakin menjulang.

"Melihat dari statiska data sosial media Instagram di Indonesia hanya beberapa bulan setelah diluncurkan, Instagram mampu meraih 1 juta pengguna pada Desember 2010. Jumlah ini meningkat terus hingga mencapai 5 juta user pada Juni, kemudian mencapai 10 juta pada September 2011. Belakangan, Instagram mengklaim anggotanya telah mencapai lebih dari 30 juta pada April 2012.”(19)

Ketiga, para ahli dan ulama yang termasuk berpengaruh ataupun yang berkedudukan di belakang layar penyiaran yang bernuansa Islami melalui internet bisa lebih fokus kepada isu bahkan kejadian memperjuangkan norma yang berlandaskan islami. Keempat, penyiaran yang bernuansa Islami via internet merupakan bagian dari salah satu pilihan masyarakat. Beraneka macam situs bisa diseleksi sesuai tema yang diinginkan atau sesuai suasana. Kelima, gaya penyajian memiliki ciri khas si pendakwah via internet dapat mencapai fragmen secara ekstensif. Keenam, kajian ilmu akan berlangsung efisien apabila diseminasi secara tidak resmi. Ketujuh, perihal yang kita ketahui dan dipelajari yaitu tokohnya ataupun seseorang yang kita senangi/sayangi akan lebih mudah dicerna dianalogikan dengan kajian popular (ortodoks) di dalam ruangan kelas. Kedelapan, adanya keinginan apabila seseorang merasa enjoy berada di rumah ataupun dipekarangan rumah. Akan lebih memudahkan baginya untuk mencerna sains membandingkan situasi yang menegangkan ataupun eksistensi secara terstruktur.(2)

Munculnya media baru digital ini sangat membantu aktivitas dakwah baraneka macam melalui akomodasi media sosial secara virtual misalnya Instagram. Dari pemaparan tersebut bahwa jaringan sosial yang menjadi trendsetter yang bisa dimanfaatkan dalam menyampaikan nilai-nilai Islam. Penelaahan melalui teknologi digital mengharuskan semua makhluk sosial belajar tanpa harus meninggalkan kampung halaman bahkan pencahariannya.

Seorang mubaligh arif dan bijaksana akan memprediksikan bahwa teknologi digital itu merupakan sebuah inovasi sains yang apabila 
difungsikan secara baik dan benar, maka bisa memberikan manfaat dan faedah yang berguna untuk seluruh umat Islam. Pandangan inilah yang sepantasnya seorang mubaligh berpikir. Bahwa teknologi itu sangat berperan penting untuk mensyiarkan agama.

\section{Metodologi Penelitian}

Metode penelitian ini adalah kualitatif dengan menggunakan framing model yang dikembangkan oleh Robert N. Entman dengan mengamati bagaimana sebuah wacana atau komunikasi ditampilkan diruang publik. Dalam framing ada dua hal yang diperhatikan pertama mengenai aspek-askpek yang ditonjolkan dari isu dan memilih isu yang disampaikan ke ruang publik.(5) Adapun objek dalam penelitian ini adalah unggahan dari pendakwah yang aktif di sosial media yakni @felixsiauw dan @Hanan_attaki. Kedua akun dai tersebut dipilih karena termasuk dai muda yang aktif di sosial media dan memiliki follower yang cukup banyak. Selain itu peneliti juga mewawancarai beberapa informan apa yang membuat mereka tertarik dengan Felix Siauw dan Hanan Attaki.

\section{Hasil dan Diskusi}

\section{Aktivisme Felix Siauw di Instagram}

Felix Yanwar Siauw (Siauw Chen Kwok), lahir di Palembang Sumatra Selatan pada tahun 1984. Menjadi seorang muallaf pada tahun 2002 yang sebelumnya dia seorang Katolik. Felix mempelajari Islam melalui teman-temanya aktivis HTI yang berada di Fakultas Pertanian Institut Pertanian Bogor. Selain itu dirinya juga berdakwah melalui bukunya dengan judul Beyond the Inspiration, Khilafah, Yuk Berhijab, Udah Putusin Aja, How To Master Your Habbits.

Felix Siauw memanfaatkan sosial media terutama facebook dan Instagram untuk menyebarkan dakwahnya dengan memanfaatkan gambar, video, warna, dan infografis. Hal ini adalah penggabungan antara bentuk-bentuk kreatif dengan subtansi konservatif. Dengan hal inilah Felix berhasil menarik minat anak muda. Namun hal yang menarik adalah pasca pembumbaran organisasi HTI (Undang-undang pembubaran HTI) dimana Felix Siauw termasuk salah satu anggotanya. Menjadikan persepsinya berubah di sosial media. Semenjak pembubaran tersebut terjadi pertentangan antara pendukung Felix Siauw dengan yang tidak sepakat dengan dakwahnya terkhusus organisasi Felix Siauw yaitu HTI. Meskipun begitu Felix tetap melanjutkan dakwahnya di sosial media dengan tidak menanggapi kolom komentar atas apa yang disampaikannya. Tema-tema yang Felix Siauw posting dalam Instagram berupa foto berisikan caption nasehat-nasehat kebaikan, beberapa video pendek yang membicarakan perihal pernikahan, serta video animasi pendek yang menarik.

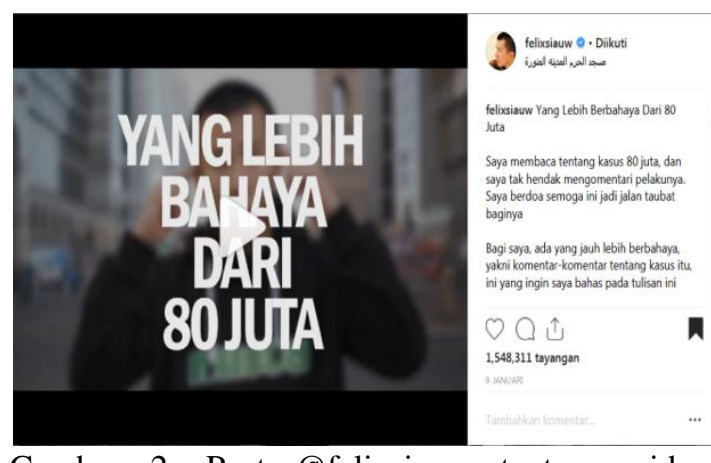

Gambar 2. Post @felixsiauw tentang video dakwah yang membahas lebih bahaya dari 80 juta.

"Yang lebih bahaya dari 80 juta. Saya membaca tentang kasus 80 juta dan saya tak hendak mengomentari pelakunya. Saya berdoa semoga ini menjadi jalan taubat baginya. Bagi saya, ada yang jauh lebih berbahaya, yakni komentar-komentar tentang kasus itu, ini yang ingin saya bahas dalam tulisan ini. Nakal itu ada dua, nakal kelakukan dan nakal pemikiran. Nakal kelakuan itu seperti anak kecil, sebabnya tak paham atau karena memang lalai. Biasanya nakal jenis ini spontanitas, dan polanya tak berulang. Beda dengan nakal pemikiran, ini lebih berbahaya, sebab dia konseptual, bentuknya ide, seperti virus, menjangkiti dan menyebar, menyebabkan pola kemaksiatan, dan tidak hanya nakal sendiri, dia mencari pengikut untuk sama-sama nakal. Nakal kelakuan berakhir dengan penyesalan, tapi nakal pemikiran mencari pembenaran, bahkan mengarang alasan. Nakal pikiran menyebabkan orang merasa wajar dengan kenakalan itu, sedangkan nakal kelakuan berakhir dengan tangisan dan minta maaf. Bayangkan, ternyata di Indonesia, ada wanita yang berkomentar seperti ini: "Saya justru penasaran bagaimana VA membangun value/nilai dirinya, sehingga orang-orang 
mau membayar tinggi di atas harga pasar reguler. Padahal, seorang istri saja diberi uang bulanan 10 juta sudah merangkap jadi koki, tukang bersih-bersih, babysitter, dll. Lalu, yang sebenarnya murahan itu siapa?", begitu. Inilah bentuk nakal pemikiran. Darimana mereka dapat pola pikir semisal ini? Sebab membaca referensi feminimisme, yang menghitung bahagia wanita hanya dari materi, hanya dari fisik, dan menihilkan Tuhan dan hari pembalasan. Jangan heran bila mereka semua dari kelompok yang sama, pembela penista agama, pembela kaum Nabi Luth, penentang poligami, ya itu-itu saja. Inilah pentingnya bagi seтиa muslimah khususnya orangtua, memahami pentingnya Islam, agar kelak anak-anak kita tidak merendahkan wanita seperti itu. Bayangkan bagaimana sakitnya perasaan orangtua mereka, saat pernikahan diremehkan dan dihinakan begitu rupa, perzinaan dianggap lebih hebat dari pernikahan"

Yang menarik adalah Felix selalu mengangkat isu-isu yang aktual dalam akunnya seperti seorang artis yang berinisial VA yang terlibat kasus prostitusi. Yang kemudian ia posting dengan video pendek dengan judul "Yang lebih berbahaya dari 80 juta" yang sudah ditonton sampai 1.528.741 tayangan dengan komentar 2.994. Dalam postingan tersebut Felix lebih memfokuskan kepada komentar dari netizen terhadap kasus VA yang di sebut dengan nakal pikiran yaitu mencari pembenaran dan mengarang alasan. Atas komentar itu kemudian Felix menyusun retorikanya dengan menyatakan bahwa "itulah akibat referensi feminis, yang menghitung bahagia wanita hanya dari materi, hanya dari fisik, dan menihilkan Tuhan dan hari pembalasan" kemudian dengan narasi selanjutnya Felix memberikan label terhadap komentar tersebut dengan mengatakan "Jangan heran bila mereka semua dari kelompok yang sama, pembela penista agama, pembela kaum Nabi Luth, penentang poligami, ya itu-itu saja". Dan diakhiri dengan nasehat untuk Muslimah yang dikhususkan terhadap orang tua agar tidak merendahkan wanita dan meremehkan pernikahan.
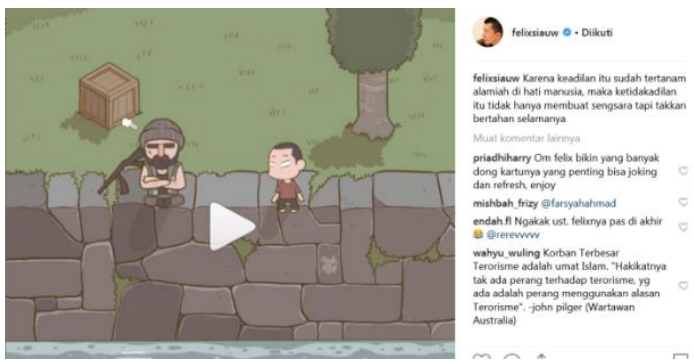

Gambar 3. Post @felixsiauw tentang video dakwah animasi tentang teroris.

"Karena keadilan itu sudah tertanam alamiah di hati manusia, maka ketidak adilan itu tidak hanya membuat sengsara tapi takkan bertahan selamanya."

Felix juga menggunakan video animasi untuk menyampaikan pesanya. Telah ditonton sebanyak 624.725. Dalam video tersebut wacana yang dihadirkan adalah masalah teroris, mengenai kasus OPM Papua. Dimana terjadi pemberontakan oleh OPM Papua dengan mengibarkan bendera, menggunakan senjata, dan juga melakukan pembunuhan atas warga sekitar tetapi hanya dianggap krimanalisasi bersenjata. Dimana pesan-pesan dakwah melalui animasi menjadi hal yang menarik terutama bagi generasi milineal karena memiliki daya pikat secara visual. Adapun konten yang dibawakan berisikan kritikan terhadap pemerintah.
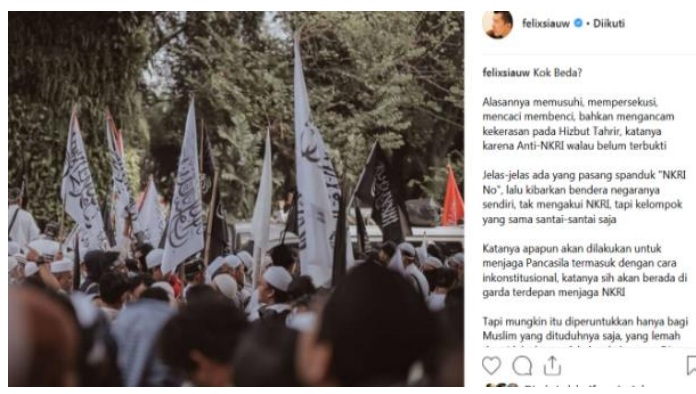

Gambar 4. Post @felixsiauw tentang gambar terkait pembubaran HTI.

"Kok beda? Alasanya memushi, mempersekusi, mencaci, membenci, bahkan mengancam kekerasan pada Hizbut Tahrir, katanya karena Anti-NKRI walau belum terbukti. Jelas-jelas ada yang pasan spanduk "NKRI No", lalu kibarkan negaranya sendiri, tak mengakui NKRI, tapi kelompok yang sama santai-santai saja. Katanya apapun akan dilakukan untuk menjaga pancasila termasuk dengan cara inkontusional, katanya sih akan berada di garda terdepan menjaga NKRI. Tapi mungkin itu diperuntukkan hanya bagi Muslim yang dituduhnya saja, yang lemah 
dan tidak akan melakukan kekerasan. Di papua? Sepertinya tidak. HTI tidak pernah bunuh orang, tidak pernah punya senjata, tapi dibuat jadi monster ganas. Itu yang di Papua hanya disebut kelompok kriminal bersenjata yang tak elok. Alasanya membakar bendera, awalnya katanya mau menyucikan bendera tauhid. Lalu dia katakan, ini bendera HTI lalu dibakar, yang benar jadi yang mana? Matimatian bilang bahwa yang dibakar bendera HTI bukan bendera tauhid. Lalu ada yang twit, "pembakar bendera tauhid itu sesat", dia mengamuk. Kalau yakin yang dibakar itu bendera HTI, harusnya kan tak perlu bawa perasaan. Atau jangan-jangan sudah sadar yang dibakar memang bendera tauhid? AlQuran dinistakan, katanya "Jangan marahmarah", Islam dicaci dia bilang, "Islam Nusantara itu ramah", Organisasinya disinggung mengamuk lagi. Cuma mau tanya, "Kok beda?" Nanti juga ada yang komentar, "Tabayun dong", tapi dalam memfitnah dan menuduh yang lain, mereka juga tidak pernah tabayun. Sekali lagi, kok beda? Wajarlah, kalau orang-orang lantas mencurigai bahwa tuduhan Anti-NKRI, Anti-Pancasila, radikal, dan lainnya, itu hanya proyek de-islamisasi saja. Wajar juga banyak meme beredar "Cukup bisikkan saja pada mereka, Felix Siauw bakal buat kajian di Papua”, supaya mereka semangat ke Papua, bela NKRI. Entah saya mau tertawa atau menangis. Tapi yang jelas, mereka saudara saya, berharap suatu saat mereka sadar dan serius berukhuwah, toleran pada perbedaan"

Dari postingan yang telah dibangun oleh Felix Siauw dalam Instagram banyak menarik generasi milineal terutama karena bahasanya lebih mudah dimengerti dan dipahami. Beberapa narasumber yang peneliti wawancarai tertarik dengan dakwah Felix mulai dari hidayah takdir seorang muslimah, politik dan sejarah Islam, nilai agama dan sosial. dimana dalam hal ini ruang sosial media menjadi tempat trend kesalehan bagi generasi milineal. Yang menarik adalah generasi milineal tidak begitu tahu apakah dai tersebut berafiliasi disalah satu organisasi, yang dipentingkah adalah cara penyampaiannya yang baik. Dari beberapa narasumber yang peneliti wawancarai hanya sedikit yang tahu kalau Felix Siauw berafiliasi dengan HTI (Hitbuz Tahrir Indonesia), kebanyakan tidak mengetahui dan hanya tertarik dengan konten yang disajikan oleh Felix Siauw. HTI diketahui memiliki wacana pendirian khilafah islamiyah yang berasal dari pemikiran Taqiyadin Al-Abani dimana bukan termasuk gerakan asli Indonesia atau disebut dengan istilah Islam Transnasional.(9). Dengan metode dakwah Felix Siauw merubah pola pergerakan HTI dengan bernegosiasi dan menampilkan dakwah yang lebih modern dengan memanfaatkan sosial media. Hingga wacana tentang HTI lebih bisa menarik kalangan generasi milineal.

Walaupun HTI sudah dibubarkan secara resmi namun hal tersebut tak menyurutkan Felix untuk melawan atas pembumbaran tersebut dengan berbagai macam argumen yang dia sampaikan melalui postingannya. Meskipun ada beberapa ulama arus utama yang mengkritik wacana HTI secara terangterangan, namun tetap saja tak menyurutkan pengikut Felix Siauw untuk tetap mengikuti. Hal ini karena model dakwah yang disajikan sederhana dan bisa dipahami bagi orang yang baru belajar agama.

\section{Aktivisme Hannan Attaki di Instagram}

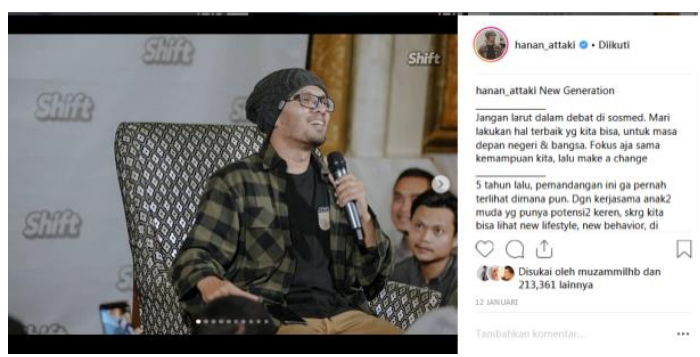

Gambar 5. Post video ceramah @ hanan_attaki.

Hanan Attaki merupakan pendakwah muda yang berasal dari Bandung yang populer semenjak ada sosial media khususnya Instagram. Pendakwah muda ini lahir pada tanggal 31 Desember 1981 di Aceh. Yang telah menempuh pendidikan tafsir Al-Quran di Fakultas Ushuludin Universitas Al Azhar, Cairo Mesir. Seringkali mengisi pengajian di Masjid Trans Studio Bandung dan pada tahun 2015 mendirikan Gerakan Pemudah Hijrah.(21)

Hanan Attaki berpenampilan dengan pakaian yang gaul dengan kaos atau kemeja flanel dan kupluk serta gaya bercerita yang kerap kali menggunakan bahasa yang sesuai dengan anak muda. Dengan pengikut Instagram sebanyak 5,2 Juta, Hanan Attaki menjadi popoler dikalangan anak muda. 
Banyak video ceramahnya yang dibagikan oleh anak muda di sosial media, khususnya tema yang berkaitan dengan masalah percintaan atau nasehat-nasehat.

Aktivisme Hanan Attaki di Instagram berupa foto-foto kegiatan serta vidoe ceramah pendek. Yang bertemakan tentang nesehat dan keshalehan seperti "Bangkrut", "Hikmah", Keberkahan", "Tinggal Doa", "Lelaki Yang Tulus Cintanya". "Doa yang tergadai" dan berbagai macam video dakwah lainya berupa nasehat-nasehat kebaikan

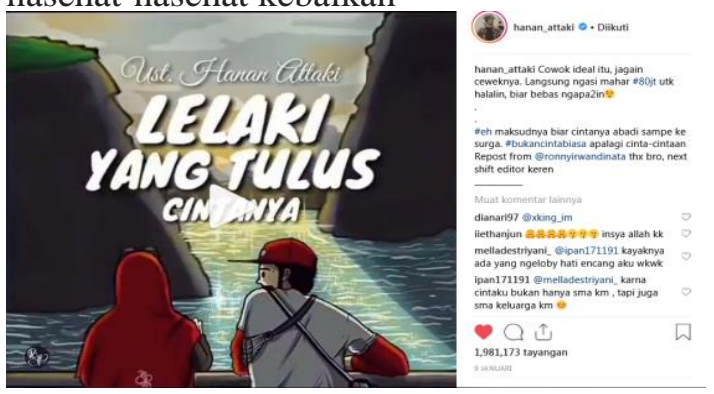

Gambar 5. Post video ceramah @ hanan_attaki.

"Cowok ideal itu, jagain ceweknya. Langsung ngasih mahar \#80jt untuk halalin, biar bebas ngapa-ngapain. Eh maksudnya biar cintanya abadi sampe ke surga. \#bukancintabiasa apalagi cinta-cintaan"

Gambar di atas salah satu dari sekian banyak video dakwah Hanan Attaki terkait masalah percintaan. Dengan judul "Lelaki yang tulus cintanya", dimana hal tersebut banyak menarik para generasi milineal yang menyenangi dakwah dengan konten masalah percintaan yang telah ditonton sebanyak 2.000.681.

Berbeda dengan Felix yang membawakan pesan dakwah politik. Dalam aktivisme Hanan Attaki lebih memfokuskan kepada trend kesalehan berupa nasehat-nasehat kebaikan dan juga tentang cinta antar lelaki dan perempuan. Selain itu Hanan Attaki juga berpenampilan berbeda dari da'i biasanya yang menggunakan peci atau surban, namun memakai pakaian kemeja flanel dan topi kupluk. Pesan dakwah Hanan Attaki juga dipromosikan melalui hobi yang dia kerjakan seperti bermain skateboar dan surfing sehingga hal tersebut menarik banyak generasi milineal yang ingin tetap menyalurkan hobinya namun tetap islami atau biasa disebut dengan Gaul Tapi Soleh.
Seperti rumusan yang digunakan Merlyna (14) dalam mengetahui keberhasilan penyebaran dakwah dapat tersebar dengan menyajikan narasi yang sederhana dan menarik. Maka video pendek Instagram yang berdurasi 1 menit menjadi sarana dakwah yang sederhana yang bisa diminati oleh generasi milineal. Selain itu juga kontenkonten yang sesuai dengan paham atau yang dirasakan generasi milineal lebih cepat tersebar dibandingkan dengan isu yang kurang menarik generasi milineal.

Meskipun kedua ustadz tersebut samasama berdakwah melalui Instagram, namun ada beberapa perbedaan yang bisa terlihat terutama mengenai politik. Dalam akunnya Felix selalu menekankan kritikannya terhadap pemerintah dan menarasikan wacana HTI dengan gaya yang menarik. Berbeda sekali dengan Hanan Attaki yang tidak begitu menyentuh ranah politik, tapi lebih ke arah trend kesalehan dengan menampilkan berislam tapi tetap gaul.

\section{Kesimpulan}

Dakwah yang dilakukan di sosial media lebih mampu menyasar generasi milineal yang sedang tumbuh dalam pencarian identitas. Dimana mereka lebih senang dengan dakwah yang disampaikan secara sederhana dan menarik. Maka kemunculan Felix Siauw dan Hanan Attaki menjadi hal yang menarik bagi generasi milineal. Meski Felix Siauw dan Hanan Attaki sama-sama berdakwah melalui sosial media dengan menggunakan postingan atau video pendek namun dalam beberapa bagian Felix Siauw lebih dominan membahas permasalahan sosial dan politik berbeda dengan Hanan Attaki yang lebih dominan membahas tentang nesehat kebaikan atau tentang cinta antara laki-laki dan perempuan. Hal ini tidak luput dari latar belakang mereka sebagai Ustadz Hitz, dimana Felix Siauw berafiliasi dengan gerakan HTI yang memiliki wacana khilafah Islamiyah sehingga dakwahnya banyak berhubungan dengan pemerintah apalagi setelah terjadi kasus pembubaran terhadap organisasi yang dilakukan oleh pemerintah. Berbeda dengan Hanan Attaki yang memiliki latar belakang lulusan Al-Azhar dimana yang dibicarakan dominan seputar trend kesalehan serta menggunakan kata-kata yang cocok untuk generasi milineal. 


\section{References}

1. Abdullah SDA. Peran Hanan Attaki Dalam Membangun Persepsi Generasi Milenial Tentang Tuhan (Analisis Isi Atas Video "Kangen" Di Youtube). 17 : 65-74, 2018.

2. Bakti AF, Meidasari VE. Trendsetter Komunikasi di Era Digital: Tantangan dan Peluang Pendidikan Komunikasi dan Penyiaran Islam. Jurnal Komunikasi V. 04, No. 01, 2014.

3. Bambang. Instagram Handbook Tips Fotografi Ponsel. Jakarta: Media Kita, 2014.

4. Cherry C. World communication: Threat or Promise? A socio-Techinical Approach. Wiley: Chichester, 1978.

5. Eriyanto. Analisis Framing (Kontruksi, Ideologi, dan Politik Media). Yogyakarta: Lkis, 2012.

6. Farhan. Pesan Dakwah Felix Siauw di Media Sosial Perspektif Meaning And Media. Al Idarah Vol. 1, No. 2: 209226, 2017.

7. Ham M. Islam Antar Teks Kuasa dan Identitas. Yogyakarta: Arti Bumi Intaran, 2018.

8. Han M. Ustadz Hits Bahasa Gaul dan Social Meida Effect. Yogyakarta: Arti Bumi Intaran, 2018.

9. Hilmy M. Akar-Akar Transnasionalisme Islam Hizbut Tahrir Indonesia (HTI). ISLAMICA Vol 6, No.1: 1-13, 2011.

10. Hoesterey JB. Prophetic Cosmopolitanism: Islam, Pop Psychology, and Civic Virtue in Indonesia. City \& Society 24: 38-61, 2012.

11. Ilaihi W. Komuniksi Dakwah. Bandung: PT Remaja Rosdakarya, 2010.

12. Ito M, Horst $\mathbf{H}$, Bittanti M, Boyd D, Stephenson BH, Lange. Living and learning with New Media: Summary of
Finding From the Digital Youth Project. Chicago: The MacArthur Foundation, 2008.

13. Jannah I. Kontestasi Makna Hijab Dalam Ruang Media Sosial Instagram. Yogyakarta: Arti Bumi Intaran, 2018.

14. Lim M. Many Clicks but Little Sticks: Social Media Activism in Indonesia. Routledge ( February 11, 2013). doi: Many Clicks but Little Sticks: Social Media Activism in Indonesia.

15. Marioni A. Karakteristik Media dan Kegiatan Integrated Marketing Communication (IMC). Jakarta: Universitas Indonesia Esa Unggul, 2011.

16. Media KC. Juni 2018, Pengguna Aktif Instagram Tembus 1 Miliar [Online]. KOMPAS.com: [date unknown]. https://tekno.kompas.com/read/2018/06 /21/10280037/juni-2018-penggunaaktif-instagram-tembus-1-miliar [22 May 2019].

17. Nisa EF. Creative and Lucrative Da 'wa: The Visual Culture of Instagram amongst Female Muslim Youth in Indonesia. Asiascape: Digital Asia 5: 68-99, 2018.

18. Saifullah M. Beyond Muslims Panic: An Exploration Upon Instagram Matchmaker In Indonesia. 1 17: 341351, 2018.

19. Tim Pusat Humas. Kementrian Perdagangan RI, Panduan Optimalisasi Media Sosial Untuk Kementrian Perdagangan RI. Jakarta: Pusat Hubungan Masyarakat, 2014.

20. Weng HW. THE ART OF DAKWAH: social media, visual persuasion and the Islamist propagation of Felix Siauw. Indonesia and the Malay World 46: 6179, 2018.

21. Wink. Profil dan Biografi Ustadz Hanan Attaki - Pendiri Pemuda Hijrah [Online]. BiografiKu.com | Profil dan Biografi Tokoh Terkenal: 2018. 
https://www.biografiku.com/biografidan-profil-lengkap-ustadz-hanan-attakipendiri-pemuda-hijrah/ [26 May 2019].

22. Dictionary by Merriam-Webster: America's most-trusted online dictionary [Online]. [date unknown]. https://www.merriam-webster.com/ [26 May 2019]. 